\title{
Legitimacy and Support for Palestinian Insurgent Groups During the Second Intifada
}

\author{
Holly Elizabeth Fuller* \\ Purcellville, Virginia
}

Bachelor of Arts in Political Science \& Religion, Wake Forest University, 2012

A Thesis presented to the Graduate Faculty of the University of Virginia in Candidacy for the Degree of Master of Arts

\author{
Department of Politics \\ University of Virginia \\ May, 2014
}

\begin{abstract}
When multiple groups are operating in a civil war context, individuals have a choice in deciding whom to support. To examine how people make this decision, existing research focuses on material incentives, defiance, and pleasure in agency. This paper offers an alternative explanation. It examines whether the legitimacy of an insurgent group during the Second Intifada leads to support. Using opinion polls from the Second Intifada on the level of trust for the Palestinian factions compared to the lagged level of support, this paper finds the legitimacy theory to be plausible. While additional testing is needed, shifts in trust lead to similar shifts in support for Palestinian groups. An exploratory case study of Hamas and its provision of services, a necessary but not sufficient condition for legitimacy, is performed to begin to examine qualitatively the legitimacy hypothesis.
\end{abstract}

* Acknowledgements: Dr. Jonah Schulhofer-Wohl, Dr. Allen Lynch, and Paromita Sen 


\section{Introduction}

During a civil war, the local population has a decision to make about whether to support the government, an insurgent group, or remain neutral. The support of the local population is a key component of a civil war. It often helps determine the war's outcome, as insurgent groups cannot blend in with the population if the local population does not support it. Also, the government needs the support of its people in order to locate the insurgents and retain control. In some civil wars there are multiple insurgent groups operating, complicating the situation even further. Lending support to any one side can be extremely risky for the individual involved. If caught the person could be denied basic services, shunned from the community, jailed, or even killed by an opposing side. In civil wars, why do citizens decide to lend support? Once a person has decided to lend support, how does he or she select a side? More particularly, how do individuals chose which insurgent group to support, if any, if there are multiple in a conflict?

This paper seeks to explain noncombatant domestic support for insurgent groups, looking particularly at how individuals choose between various insurgent groups especially if each group has the similar goal of taking control of territory from the incumbent. The main contribution of this paper is examining how the legitimacy of insurgent groups affects domestic support. In the international community, governments that are legitimate seem to have more domestic support. As a result, I would expect the same logic to apply to insurgent groups. Those insurgent groups perceived as legitimate will have more domestic support. 
To assess the validity of the hypothesis, I will examine levels of support for Palestinian insurgent groups during the Second Intifada. As there were multiple groups operating, Palestinians had options when deciding whom to support. In order to test the hypothesis, I will compare support levels for Palestinian groups to trust data points for the preceding year. The trend for support level during the Second Intifada should mimic that of trust levels if trust determines support. While this research will not rule out alternative explanations for support, it highlights an overlooked hypothesis. As the focus of this study is on the subnational level of the Second Intifada, the results may not be generalizable to other civil war contexts. I will start by exploring the literature related to this paper. Then I lay out the methodology used to examine the hypothesis, followed by a brief background of the Second Intifada. Next, I will explore the three major insurgent groups competing for popular legitimacy: Fatah, Hamas, and Palestinian Islamic Jihad. After presenting and analyzing the data, I perform an exploratory case study of Hamas' legitimacy and support. Finally, I make some concluding remarks, discuss the significance of the work, and suggest future research endeavors.

\section{Literature}

The literature on noncombatant support during civil wars covers a variety of explanations. Some common explanations for domestic support include: material incentives, defiance, and pleasure of agency. Material incentives can be a motivating factor for participation. The state produces public goods, which are "non-rival" and "non-excludable"(Olson 1965). Public goods are "non-rival" because multiple 
people can consume the good without them having to compete for it (Olson 1965). Due to the fact that one person cannot stop another from partaking in the good, public goods are also "non-excludable" (Olson 1965). One example of public goods as a motivating factor in civil war is the El Salvador case. The good, in this case land, was available to everyone and was not contingent on participation. However, insurgencies can offer selective incentives to curb freeriding, as only active participants will receive the good. Incentives can vary from money, food, land, or security. Samuel Popkin (1979) demonstrates how peasants were offered material benefits in Vietnam in exchange for their participation. During the pre-capitalist era in corporate villages, the landlord controlled the distribution of "credit, drafting animals, housing, and seeds" to the peasant (Popkin 1979: 2). The landlord therefore is in control of selective incentives because he can determine the quantity given to the peasant and make it contingent on support.

Another explanation for domestic support is defiance. Defiance is resistance that occurs in response to actions taken by the incumbent that are perceived as unjust. This can also be seen as the expression of grievances. Civilians will be pushed towards supporting the insurgency when their neighbors or relatives suffer (Wood 2003). They express their outrage through support of the opposing group. It is often propelled by a moral commitment in response to incumbent's behavior (Wood 2003). Humphreys and Weinstein suggest that participation due to grievances can occur through three mechanisms: economic deprivation, political marginalization from decision-making, and the process itself (2008). 
Elisabeth Wood argues that campesino participation occurred in El Salvador due to the pleasure of agency. The campesinos "took pride, indeed pleasure, in the successful assertion of their interests and identity" (2003: 18). Through interviews with campesinos, Wood stresses the importance of individual agency as the motivating factor behind participation. These peasants had increased pride because they saw themselves as creating a more just world (Wood 2003).

While these studies provide plausible explanation for domestic support, another explanation seems plausible. I propose to examine this new explanation for domestic support. Support could be caused by the legitimacy of the insurgent group. As the incumbent regime confronts the insurgency, often some of its legitimacy is eroded. Insurgent groups can build up their own legitimacy in order to attract members and gain support. While legitimacy is not necessary to run a state or group because coercion can be an alternative method, legitimacy makes governance more efficient and less costly. Therefore, insurgent groups should try to increase their legitimacy throughout a conflict to gain support and prepare for governance.

\section{Legitimacy}

As Levi, Sacks, and Tyler in “Conceptualizing Legitimacy, Measuring Legitimating Beliefs" argue, "Legitimacy denotes popular acceptance of government officials' right to govern" (2009: 354). This same implication about legitimacy can apply to insurgent groups. A person will support the group that he or she feels has a right to rule. The group with more popular acceptance is more likely to control that specific area. Groups seen as legitimate induce citizens to provide voluntary 
support. Tom Tyler defines legitimacy as "the belief that authorities, institutions, and social arrangements are appropriate, proper, and just" (2006: 376). He suggests that a major part of what makes up legitimacy is obligation or the willingness to obey (Tyler 2006). The voluntary nature of legitimacy is one of its defining characteristics. Max Weber examines power and authority in The Theory of Social and Economic Organization (1947). He suggests that authority is based on the right to rule, and power is the ability to compel another (1947). The right to rule stems from the concept of fairness, as fair procedures induce higher levels of commitment to the organization (Tyler 2006). Fair procedures are essential to maintaining legitimacy and hence authority. Mitchell Seligson demonstrates that corruption erodes political support and trust (2002). Corruption erodes legitimacy because the government is no longer viewed as fair.

Legitimacy is also a topic in the counterinsurgency (COIN) literature. According to Cohen et al, legitimate governments are distinguished by five key factors: "free, fair, and frequent selection of leaders; a high level of popular participation in and support for the political process; a low level of corruption; a culturally acceptable rate of political, economic, and social development; and a high level of regime support from major institutions" (2006: 49). These characteristics of legitimate governments can apply to insurgent groups as well, especially when they are trying to become the new government. Cohen et al suggest that counterinsurgency operations cannot be successful unless legitimacy is restored (2006). Similarly, the U.S. COIN field manual states, "U.S. and [host-nation] military commanders and the [host-nation] government together must devise the plan for 
attacking the insurgents' strategy and focusing the collective effort to bolster or

restore government legitimacy" (Eikenberry 2013). As rebuilding legitimacy is key to the government's ability to defeat the insurgency, it is logical that building the legitimacy of the insurgency would allow it to defeat the regime.

\section{Methodology}

I will test the hypothesis that greater legitimacy leads to more domestic support.

$H$ : An increase in the relative legitimacy of a group will lead to an increase in the amount of domestic support for that group.

The case used to examine the hypothesis is the Second Intifada from 2000 to 2005 . I will look at those civilians who chose to support the insurgency and those who remained neutral. During the Second Intifada, there was a large percentage (ranging from 17\% to 35\%) of the population who supported no group (Jaeger et al 2011). Of those Palestinians who did choose to support a group, legitimacy effected their decision. In the case of the Palestinian-Israeli conflict, Palestinians view the Israeli government as illegitimate due to Israel's settlements in the occupied territory, and its occupation of that territory which occurred during the 1967 SixDay War. As a result of this general viewpoint, the Israeli government will not be examined in the context of the Second Intifada. Next it will be necessary to examine how civilians chose which insurgent group to support if they decided to support any group at all. For my hypothesis to be validated, support should be given to the 
group deemed the most legitimate. A civilian may be trying to defy the incumbent, but should want to lend support to the most legitimate alternative.

The Second Intifada is a useful case because the civilian population had a variety of insurgent groups to choose from: Fatah, Hamas, Popular Front for the Liberation of Palestine (PFLP), and Palestinian Islamic Jihad (PIJ). Many different factions in Palestine have developed due to differences in ideology, alliances with other Arab states, and their methods for obtaining goals (Farsoun \& Aruri 2006). As the population has multiple options, legitimacy is more likely to play a role. People are less likely to go with the majority but rather will make a decision for themselves, especially as some of the groups have similar support levels and no group has the clear majority.

For this study, the independent variable is legitimacy. Ideally, three key aspects would be used to examine the legitimacy of insurgent groups: the security provided by the insurgent group, the services provided by the group, and the doctrine of the group. Security is a key job of a state, and as these groups intend on replacing the state, they must be prepared to overtake the state's functions. If people feel insecure because their safety is up in the air, then they will be less likely to see the group as legitimate. Similarly, states provide services to their people. These services allow civilians' daily lives to function smoothly, whether it is due to education or healthcare facilities. The provision of services, especially replacing the state in this arena, will allow a group to be seen as the right authority and will encourage obedience. Additionally, "experiencing fair procedures when dealing with authorities generally encourages people to become committed to 
organizations, leading to a variety of forms of cooperation" (Tyler 2006: 380). Doling out the services fairly to the population will most likely lead to more cooperation. Finally, and most importantly, is the doctrine of the group. Whatever the group believes or commands must be followed through. Insurgent groups that break their own doctrine will damage their image as a fair group and will lose legitimacy as a result. Due to data limitations, it is not feasible to delve into each of these characteristics. However, for an ideal research design one would gather information on each of these aspects for the respective groups and determine if their combination lead to more support. At the end of the quantitative data section, I will conduct an exploratory case study of Hamas looking specifically at its provision of services. While this is only one of many characteristics that lead to legitimacy, it will be useful to begin to see if Hamas' provision of services appears to affect its level of support. The provision of services is a necessary but not sufficient aspect that makes up legitimacy. Therefore, I am not making a case in favor of the material incentives argument because the legitimacy explanation subsumes this argument.

While I will describe the doctrine of each insurgent group, this data is very outdated for the context of the Second Intifada because the groups have not updated their principles recently. For example, Fatah's doctrine has not been updated since 1968, and Hamas' charter since 1988. Additionally, using the three characteristics discussed above as a measure of legitimacy may be problematic. For instance, people may be more likely to support a group due to the provision of services, regardless of whether or not they view the group as legitimate. Regardless, 
provision of services, especially the fairness of their distribution, seems to be a key component of legitimacy, which is why this will be examined further in the exploratory case study of Hamas. However, in order to provide preliminary support to my hypothesis, I need to find a measure of legitimacy. For this study, I will use the Jerusalem Media and Communications Center (JMCC) polls. The JMCC conducted 14 polls throughout the Second Intifada asking about the level of trust for the various Palestinian factions. These polls occurred between December 2000 and December 2005. They did not occur at regular intervals. While I recognize there is a gap between the concept and operationalization of legitimacy, measuring trust gets towards the idea of legitimacy because people will only trust governments they perceive as fair. To reiterate, Levi, Sacks, and Tyler found: "the extent to which citizens have trust and confidence in the government...has a direct effect on valuebased legitimacy" (2009: 356). Trust creates the perception of legitimacy a group earns; therefore, trust helps bring about a willingness to obey. As was the case with measuring legitimacy, trust is a difficult concept to locate qualitative data on without performing extensive fieldwork. Therefore, the JMCC poll is the best solution. JMCC specifically asks respondents "Which Palestinian faction do you trust the most?"1 Respondents are able to select from a wide range of the factions, but the most common responses were: don't trust anyone, Fatah, Hamas, and Palestinian Islamic Jihad.

The dependent variable is domestic support. Elizabeth Wood defines support for the insurgency as "provisions to the insurgents of information and

${ }^{1}$ http://www.jmcc.org/polls.aspx 
supplies beyond the contribution necessary to remain in contested areas, and the refusal to give information and supplies to government forces beyond the necessary contribution" (2003: 17). This support must be voluntary. While Wood notes that her definition is for support, she seems to really be discussing participation because the campesinos are actively involved in the insurgency. I will look at support measured by public opinion polls. Greater support for a group is likely to lead to higher levels of participation by stated supporters. The data on support for the Palestinian factions comes from Jaeger, Klor, Miaari, and Paserman's article, “Can Militants Use Violence to win Public Support? Evidence from the Second Intifada" (2011). Jaeger et al combine a series of opinion polls conducted by the Development Studies Program at Bir Zeit University. Each poll had 1,200 observations with about $65 \%$ of respondents residing in the West Bank or Jerusalem and the rest from the Gaza Strip (Jaeger et al 2010). The question asked of respondents was "Which of the following political groups do you support?" (Jaeger et al 2011). Respondents of the poll could select Fatah, Hamas, Palestinian Islamic Jihad, the Popular Front for the Liberation of Palestine (PFLP), the Democratic Front for the Liberation of Palestine (DFLP), or no one. The two leftist groups, PFLP and DFLP, were combined in the data into one group, coded as other. Other Palestinian groups with Islamic leanings were combined with Palestinian Islamic Jihad. ${ }^{2}$

\footnotetext{
2 See Jaeger et al's piece for more detailed coding rules. http://belfercenter.ksg.harvard.edu/files/uploads/mei/conference/pasermanpalestinianheartsandminds.pdf
} 
A key distinction in this research is that between trust and support. While it may appear self-evident that greater trust leads to more support and that I am in fact measuring support leading to support, the two concepts are separate. Support is different from trust because it implies a willingness to take action in order to assist a group, whereas trust is just having faith. To reiterate, legitimacy is being operationalized as trust, due to the lack of data on legitimacy specifically. Additionally, it is possible to support a government without actually trusting it. A hypothetical example would be a situation in which support is coerced by the government. As a result, the people do not actually trust the government, but they do lend it support. The most obvious example would be that of the long-standing dictatorships that were overthrown during the Arab Spring. For instance, Hosni Mubarak ruled Egypt for almost 30 years. While Mubarak did not allow any public opinion polls to be conducted about his approval rating, he did institute the first presidential election in 2005. Although the 2005 election is far from an ideal measure of support due to the fact that only $25 \%$ of eligible voters turned out, Mubarak won the election with $88 \%$ of the vote. Discussing his observation of the election, Brian Whitaker noted, "Support for Mubarak among the poor and ultrapoor is difficult for outsiders to comprehend, but the Arabic version of "the devil you know is better than the devil you don't know" was much heard on polling day" (2005). His observation highlights the fact that people will support corrupt, illegitimate governments even if they do not trust them. Support for regimes, like Mubarak's, might stem from fear or a lack of power. Even though the 2005 election results are not a perfect measure for Mubarak's support, the fact that his regime 
lasted for approximately 30 years illuminates the fact that although Mubarak was not trusted by his people, his regime maintained domestic support for a significant period of time. The example of Mubarak's rule in Egypt underscores the differentiation between trust and support, and having one does not automatically entail a government has the other.

In order to test the hypothesis that legitimacy leads to support, I will compared the JMCC trust opinion poll to Jaeger et al's domestic support levels. Using the average trust level for the preceding year, Jaeger's support level in the following year should follow a similar pattern. Examining the pattern for each Palestinian group will allow me to see if the levels of trust and changes in it corresponds with support.

One concern is that my data may have endogeneity bias because greater levels of support could be leading to more legitimacy. As a group gains followers, other citizens see that their peers respect it, which may lend the group more legitimacy. As mentioned earlier, Levi, Sacks and Tyler (2009) observe that legitimacy denotes "popular acceptance". ${ }^{3}$ However, I can be relatively confident in overcoming endogeneity bias. None of the Palestinian groups I look at ever hold over $50 \%$ of the population's support. As a result, no group seems to have popular acceptance numerically, rather each group is vying to be the legitimate representative of Palestinians. Therefore, it seems plausible that the relative legitimacy of the Palestinian factions could be driving support levels.

\footnotetext{
${ }^{3}$ Emphasis Added
} 


\section{Background on the Second Intifada}

Often considered as a continuation of the Intifada of 1987, the Second Intifada started in September 2000 amid the breakdown of peace negotiations between the Palestinians and the Israelis that had been initiated by the signing of the Oslo Accords. Ariel Sharon, the Likud party Prime Minister candidate visited the Temple Mount and provocatively stated, "The Temple Mount is in our hands and will remain in our hands" (Goldenberg 2000). Sharon's visit prompted a Palestinian protest that became unruly. Israeli riot police responded with tear gas and rubber bullets, and the Second Intifada had begun. While Sharon's visit to the Temple Mount is one explanation for the Second Intifada, there have been other accounts in which the Palestinians state it was planned in advance. Palestinian Authority Communications Minister, 'Imad Al-Faluji, on a visit to the 'Ein Al-Hilweh Palestinian refugee camp in Lebanon, stated, "Whoever thinks that the Intifada broke out because of the despised Sharon's visit to the Al-Aqsa Mosque, is wrong, even if this visit was the straw that broke the back of the Palestinian people. This Intifada was planned in advance, ever since President Arafat's return from the Camp David negotiations" (2001). Several other Palestinian leaders repeated the idea of the Second Intifada being planned, rather than spontaneous.

The Second Intifada was characterized by the use of suicide bombing on the part of the Palestinians. Suicide bombing prompted Israel to build the West Bank Security Structure that would limit the movement of Palestinians. An Israeli strategy "Operation Shield" entailed the invasion and reoccupation of much of the West Bank in April 2002. Israel also effectively implemented an assassination plan 
targeting key Palestinian officials, including Abu Ali Mustafa and Salah Shehade. After Yasser Arafat's death, Mahmoud Abbas was elected as the new chairman of the Palestinian Authority. At his inauguration, Abbas called for a ceasefire between Israel and Palestine and convinced the various Palestinian leaders to agree to stop attacking Israelis. In February 2005, Abbas and Sharon declared a truce and agreed to an informal ceasefire. Two days later, Hamas declared that the ceasefire did not apply to them, as seen by their attacks on the Gush Katif settlement. While the ceasefire did not hold, the truce between Abbas and Sharon generally marks an end to the conflict because it deescalated the situation. However, for this paper I will mark the end of the Second Intifada with Hamas' participation in the Palestinian legislative elections on January 25,2006 , as this will allow the data to show the trust levels from the last year of the Intifada and the corresponding support levels in 2006. The next section will outline the major Palestinian groups and their doctrine, which is one aspect that makes up legitimacy.

\section{The Palestinian Groups}

\section{Fatah}

Fatah, or the Movement for the National Liberation of Palestine, was founded by Yasser Arafat, Khalil al-Wazir, and Khalid al-Hasan in 1959. During the time of its founding, Fatah was unique in going against the pan-Arabism tide and believing that the Palestinian cause had to be won by Palestinians (Farsoun \& Aruri 2006). Fatah was the first Palestinian group to call for guerilla warfare in order to liberate Palestine from Israel. They laid out four stages: "hit-and-run operations, limited confrontation, temporary occupation of liberated zones, and, finally, permanent 
occupation of liberated areas" (Farsoun \& Aruri 2006: 182). On January 1, 1965, Fatah initiated its first guerilla attack on Israel. When the Arab states were defeated in the 1967 Six-Day War, the balance of power between Palestinian groups shifted in favor of the guerilla groups like Fatah. In 1968, Fatah gained control of the Palestine Liberation Organization (PLO) with Arafat as its leader.

Fatah's charter written in 1968 remained unaltered and in place during the Second Intifada. The charter declares Palestine's borders are the same as during the British Mandate Period. According to Article 7, Palestinians "must be prepared for the armed struggle and ready to sacrifice his wealth and his life in order to win back his homeland and bring about its liberation." ${ }^{4}$ Furthermore, Article 9 declares:

Armed struggle is the only way to liberate Palestine. Thus it is the overall strategy, not merely a tactical phase. The Palestinian Arab people assert their absolute determination and firm resolution to continue their armed struggle and to work for an armed popular revolution for the liberation of their country and their return to it. ${ }^{5}$

According to Fatah's doctrine, armed struggle is a strategy for achieving liberation. In order for Fatah to maintain its legitimacy, it therefore must continue this armed struggle until liberation is achieved; otherwise, Fatah is violating its doctrine, which damages its legitimacy. Fatah also declares its dedication to Arab unity as "Arab unity leads to the liberation of Palestine, the liberation of Palestine leads to Arab unity." ${ }^{6}$ Therefore, Fatah must be persistent in pursuing its goal of Arab unity to maintain its legitimacy.

\footnotetext{
${ }^{4}$ http://avalon.law.yale.edu/20th_century/plocov.asp

${ }^{5}$ IBID

${ }^{6}$ IBID
} 


\section{Hamas}

Hamas emerged in 1987 during the First Intifada, organized by the clerical leadership of the Islamic movement. As Palestine is the holy land for Muslims, Islamic ideology called for it to be liberated by jihad or "struggle" (Farsoun \& Aruri 2006). Hamas' original goal was to liberate all of Palestine through an armed struggle. Hamas did not join the PLO, and rejected the Oslo Accords, which created the Palestinian Authority (PA).

Approved in 1988, the Charter of the Islamic Resistance Movement (Hamas) discussed the PLO. Article 27 states:

Secular ideology is in total contradiction to religious ideologies, and it is upon ideology that positions, actions, and decisions are made. From here, with our respect for the Palestine Liberation Organization and what it might become, and not understanding its role in the Arab-Israeli struggle, we cannot exchange the current status and future of Islam in Palestine to adopt secular ideology. (Farsoun \& Aruri 2006, 430)

As its charter suggest, Hamas was constructed as an alternative leadership organization for Palestinians. Compared with Fatah, Hamas is more Islamist in its ideology. Hamas' charter declares, “There is no solution for the Palestinian question except through Jihad. Initiatives, proposals and international conferences are all a waste of time and vain endeavors. The Palestinian people know better than to consent to having their future, rights and fate toyed with." ${ }^{\prime 7}$ This declaration from Article 13 shows that, in principle, Hamas will not accept any negotiated settlement to the Arab-Israeli conflict and will pursue armed struggle to achieve its ends. Not only will jihad be the means of liberation, but it is also compulsory. As Article 15 highlights, "The day that enemies usurp part of Moslem land, Jihad becomes the

${ }^{7}$ http://avalon.law.yale.edu/20th_century/hamas.asp 
individual duty of every Moslem. In face of the Jews' usurpation of Palestine, it is compulsory that the banner of Jihad be raised." 8

\section{Palestinian Islamic Jihad}

Fathi Shaqaqi, Sheikh Abd al-Aziz Awda, and other Palestinian radicals living in Egypt founded Palestinian Islamic Jihad (PIJ) in 1979. They formed PIJ after splitting with the Muslim Brotherhood who was becoming too moderate from their viewpoint. After the assassination of Egyptian President Anwar Sadat, PIJ was expelled to the Gaza Strip. Inspired by the 1979 Iranian Revolution, PIJ "blended Palestinian nationalism, Sunni Islamic fundamentalism, and Shi'a revolutionary thought into its ideological agenda."9 For the PIJ, the Iranian Revolution was a model that could be mimicked in Palestine. PIJ began its jihad activities in Israel in the 1980s. Palestinian Islamic Jihad is a small group, of approximately 1,000 active participants, when compared to Fatah and Hamas. PIJ's main focus has been committing terrorist acts against Israel, rather than the provision of services to the local population. ${ }^{10}$

The by-laws of PIJ start with a definition of the movement: "The Islamic Jihad Movement in Palestine is a revolutionary jihad Movement embracing Islam as Religion and State. It is the vanguard of the Islamic Revolutionary Movement."11 Like Hamas, PIJ rejects a peaceful solution to the Arab-Israeli conflict. When laying

\footnotetext{
8 IBID

${ }^{9}$ Study of Terrorism and Responses to Terrorism. <http://www.start.umd.edu/start /data_collections/tops/terrorist_organization_pr ofile.asp?id=82>

${ }^{10}$ START Profile. <http://www.start.umd.edu/start/data_collections/tops/terrorist _organization_pr ofile.asp?id=82>

${ }^{11}$ By-laws. < http://www.investigativeproject.org/documents/case_docs/687.pdf>
} 
out the political constraints of its organization, PIJ's by-laws call for "the rejection of any peaceful solution for the Palestinian Cause, and the affirmation of the jihad solution and the martyrdom style as the only option for liberation."12 Unlike Hamas and Fatah, PIJ specifically calls for martyrdom, rather than an armed struggle or jihad. PIJ's by-laws discuss the legitimacy of its leadership. It states, "This command draws its legitimacy from God, His Prophet, and the believers in the Movement and the workers for the interest of Islam and Muslims."13 For PIJ, it seems likely that support will come from those with a religious affinity for the group as those people will be more likely to trust in PIJ's leaders. PIJ's doctrine also "prohibits the interIslamic conflict and considers the fighting between a Muslim and another forbidden."14 This statement has theoretical consequences because if PIJ conflicts with Hamas, it would be breaking its doctrine.

\section{Other Palestinian Factions}

Many other Palestinian groups operated during the Second Intifada.

However, Fatah, Hamas, and PIJ maintained the largest presence during the period. Some other mentionable Palestinian Factions are the Popular Front for the Liberation of Palestine (PFLP) and the Democratic Front for the Liberation of Palestine (DFLP). Founded by George Habash in December 1967 in the wake of the Six-Day War, the PFLP was inspired by Marxist/Leninist ideology. ${ }^{15}$ The PFLP believed that Arab unity was the key to freeing Palestine. They thought a revolution

\footnotetext{
12 IBID

13 IBID

14 IBID

${ }^{15}$ START Profile. <http://www.start.umd.edu/start/data_collections /tops/terrorist_organization_profile.asp?id=85>
} 
in the Arab world would precede the Arab struggle for Palestine (Farsoun \& Aruri 2006). With the decline of Soviet support in the 1980s, the PFLP became a marginalized faction in Palestinian politics. ${ }^{16}$ Nayaf Hawatmeh founded a splinter group of the PFLP, the DFLP in 1969. The DFLP was more leftist in its ideology hoping to promote Marxist revolutions throughout the Arab world in order to liberate Palestine. Like the PFLP, the DFLP received backing from the Soviet Union and its influence decreased with the withdrawal of Soviet aid. ${ }^{17}$

\section{Findings}

Figure 1 depicts the trend in the percentage of Palestinians who trust the major Palestinian groups. Fourteen JMCC public opinion polls were conducted during the Second Intifada from December of 2000 to December of 2005. Throughout the Second Intifada, Fatah was the group with the highest trust levels. Fatah peaked in December 2004 with 41.4\% trust levels. However, its lowest trust level was 22.6\% in April 2003. At times, the percentage of Palestinians who trusted no group surpassed Fatah. The large percentage of trust in no group seems to suggest that there is no clear legitimate faction for Palestinians. This finding definitely seems plausible. While Fatah was the primary faction, the signing of the Oslo Accords created a rift in Palestinian society. Hamas and PIJ openly reject the Oslo Accords. While the Oslo Accords were popular originally, the Accords have not been followed through, and many Palestinians faced economic deterioration as a

\footnotetext{
16 IBID

17 START Profile. < http://www.start.umd.edu/start/data_collections/tops /terrorist_organization_profile.asp?id=39>
} 
result. Therefore, other groups gained in support, and Fatah lost some of its legitimacy for supporting the Oslo Process.

Hamas, the group with the second largest trust levels, hovers below and above the 20\% mark. Hamas received its highest percentage of trust in June 2002 and October 2003 with $22.6 \%$. With $17.7 \%$ of Palestinians' trust, Hamas' lowest trust level occurred in April 2001. Palestinian Islamic Jihad maintained the third highest trust levels for any faction. PIJ's trust levels fluctuate around the 5\% mark, hitting a highpoint in April 2003 with 6.3\%. Curiously, PIJ's highpoint occurs simultaneously as Fatah's low point. During the first JMCC opinion poll of the Second Intifada, PIJ received its lowest trust percentage with 3\%.

\section{Figure 1: Trust Trend for the Palestinian Factions During the Second Intifada}

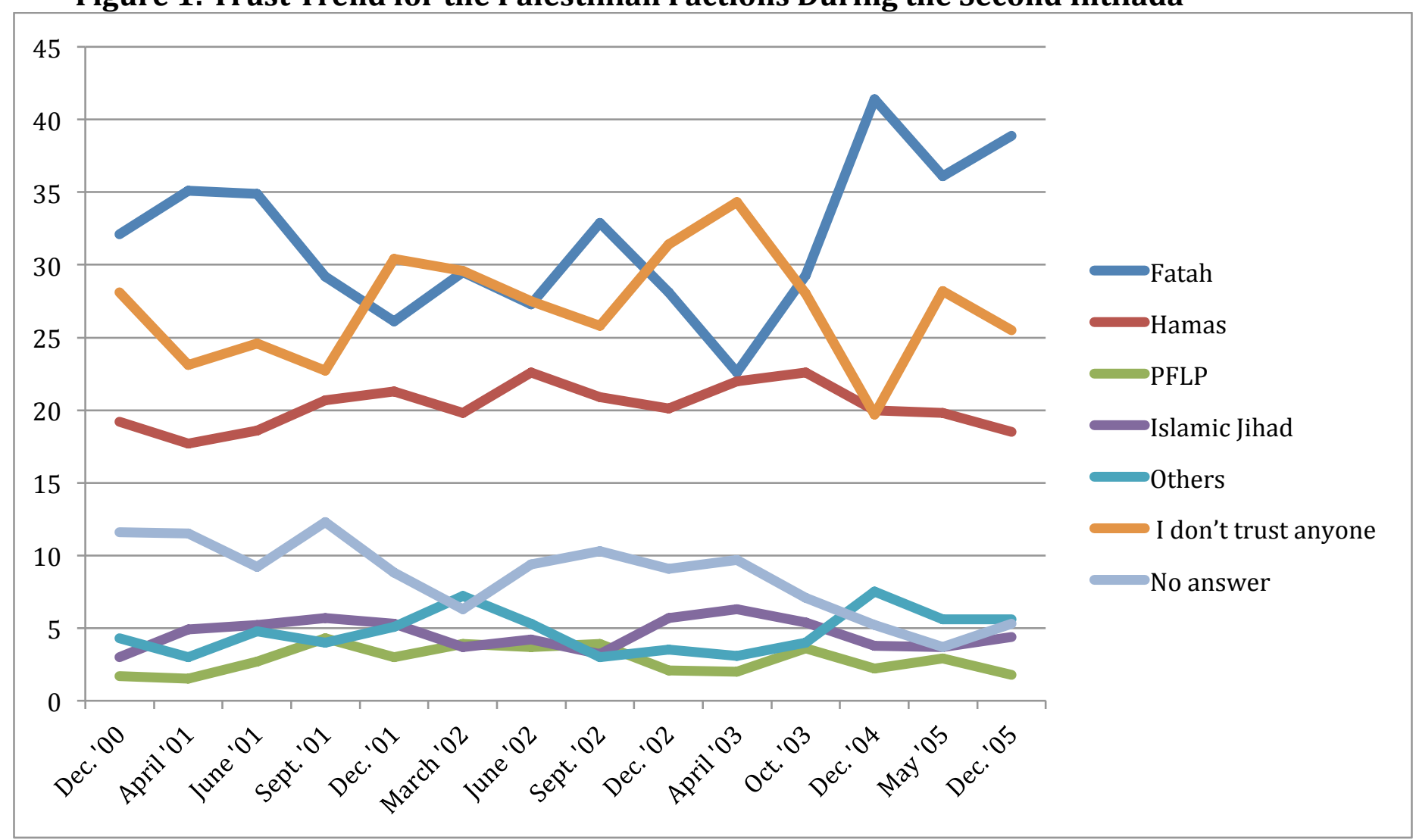

Source: JMCC Opinion Polls from December 2000 to December 2005 
The Trust levels in Figure 1 seem to correspond with the amount of support each group receives as depicted in Figure 2. Fatah averages 29.13\% of Palestinian support. Fatah has the highest level of support during this period with 'no group' coming in second. The Palestinians who support no group are most likely those people who decided to remain neutral in the conflict. As the faction with the second highest level of support, Hamas averages a 23\% support level. One major difference between Figure 1 and Figure 2 is that PIJ comes in fourth, rather than third, in Figure 2 for the largest percentage of support. However, this result could be driven by the DSP data. DSP combines PFLP with all the other Palestinian groups, but the JMCC poll leaves it separated.

Figure 2: Percentage Support for the Palestinian Factions During the Second Intifada

\begin{tabular}{lcccccccc}
\hline & \multicolumn{7}{c}{ Year } \\
\cline { 2 - 8 } Factions & $\mathbf{2 0 0 1}$ & $\mathbf{2 0 0 2}$ & $\mathbf{2 0 0 3}$ & $\mathbf{2 0 0 4}$ & $\mathbf{2 0 0 5}$ & $\mathbf{2 0 0 6}$ & $\begin{array}{c}\text { Entire } \\
\text { Period }\end{array}$ \\
\hline \multirow{3}{*}{ Fatah } & & & & & & & \\
& 22.91 & 23.22 & 27.15 & 32.07 & 43.36 & 34.40 & 29.13 \\
Hamas & $(815)$ & $(552)$ & $(999)$ & $(1,151)$ & $(519)$ & $(1,034)$ & $(5,070)$ \\
& 19.79 & 21.54 & 16.82 & 22.79 & 22.64 & 35.93 & 23.00 \\
Palestinian Islamic Jihad and other Islamic Factions & $(704)$ & $(512)$ & $(619)$ & $(818)$ & $(271)$ & $(1,080)$ & $(4,004)$ \\
& 9.08 & 9.09 & 15.05 & 7.11 & 9.44 & 6.49 & 9.51 \\
Others & $(323)$ & $(216)$ & $(554)$ & $(255)$ & $(113)$ & $(195)$ & $(1,656)$ \\
& 17.29 & 13.46 & 6.55 & 8.64 & 5.60 & 5.66 & 9.90 \\
No One & $(615)$ & $(320)$ & $(241)$ & $(310)$ & $(67)$ & $(170)$ & $(1,723)$ \\
& 30.92 & 32.69 & 34.43 & 29.40 & 18.96 & 17.53 & 28.46 \\
Total & $(1,100)$ & $(777)$ & $(1,267)$ & $(1,055)$ & $(227)$ & $(527)$ & $(4,953)$ \\
& 100.00 & 100.00 & 100.00 & 100.00 & 100.00 & 100.00 & 100.00 \\
& $(3,557)$ & $(2,377)$ & $(3,680)$ & $(3,589)$ & $(1,197)$ & $(3,006)$ & $(17,406)$ \\
\hline
\end{tabular}


Note: The number in parenthesis is the number of observations. Source: Jaeger et al's calculations based on DSP polls ${ }^{18}$

Figure 3, located in the appendix, depicts the average percentage of Palestinians that trust the major factions during the Second Intifada. To see if legitimacy has an effect on domestic support, I will take the average percentage of trust for each year and compare it to the following year's support level. Using graphical representation, the trust trend should be mirrored by the support trend. As seen in Figure 4, Fatah's support measure mimics the trust level; with the exception that there is a slight decrease in trust in 2003, but support during the following year actually increases. Similar results are achieved for Hamas, as depicted in Figure 5. Overall, support tends to follow the same pattern as the trust levels. However, between 2000 and 2001, the percentage of Palestinians who trust Hamas remains essentially constant, yet support levels from 2001 to 2002 increase.

\footnotetext{
${ }^{18}$ Jaeger, David A.; Esteban F. Klor; Sami H. Miaari; and M. Danielle Paserman. 2011. Can Militants Use Violence to Win Public Support? Evidence from the Second Intifada. Journal of Conflict Resolution. Forthcoming. $<$ http://people.bu.edu/paserman/papers/Jaeger-Klor-MiaariPaserman_CanMilitantsUseViolence_February2011.pdf>
} 
Figure 4: Comparison of Trust and Support for Fatah

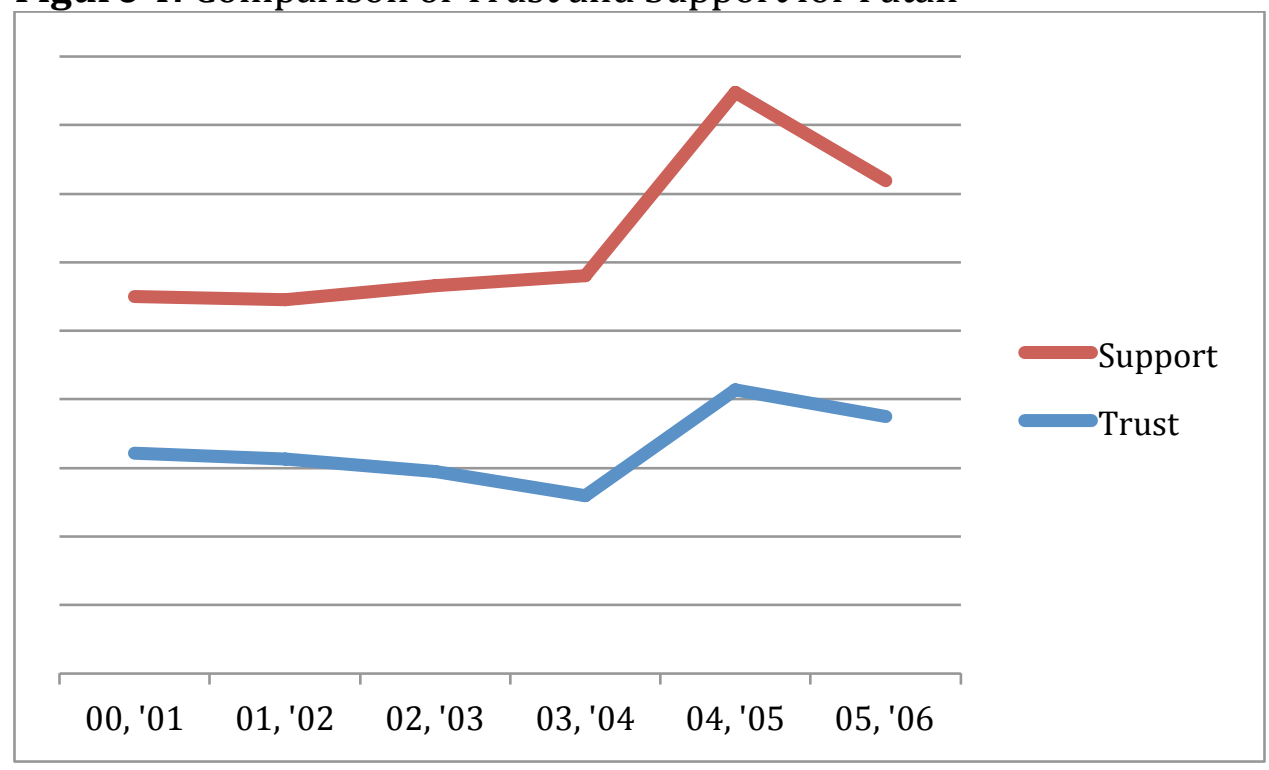

Note: The first year in the pair corresponds to the date point for trust, and the second year to the data point for support.

Figure 5: Comparison of Trust and Support for Hamas

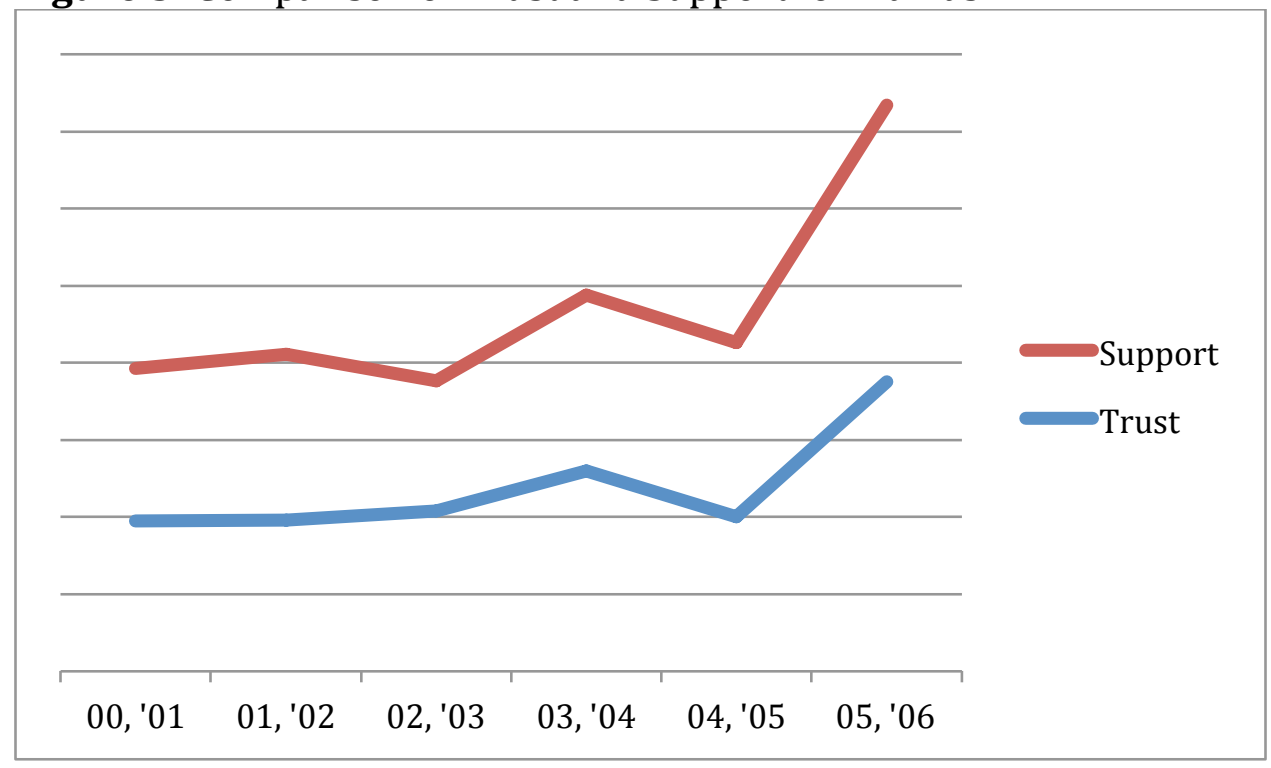

Note: The first year in the pair corresponds to the data point for trust, and the second year to the data point for support. 
Figure 6: Comparison of Trust and Support for PIJ

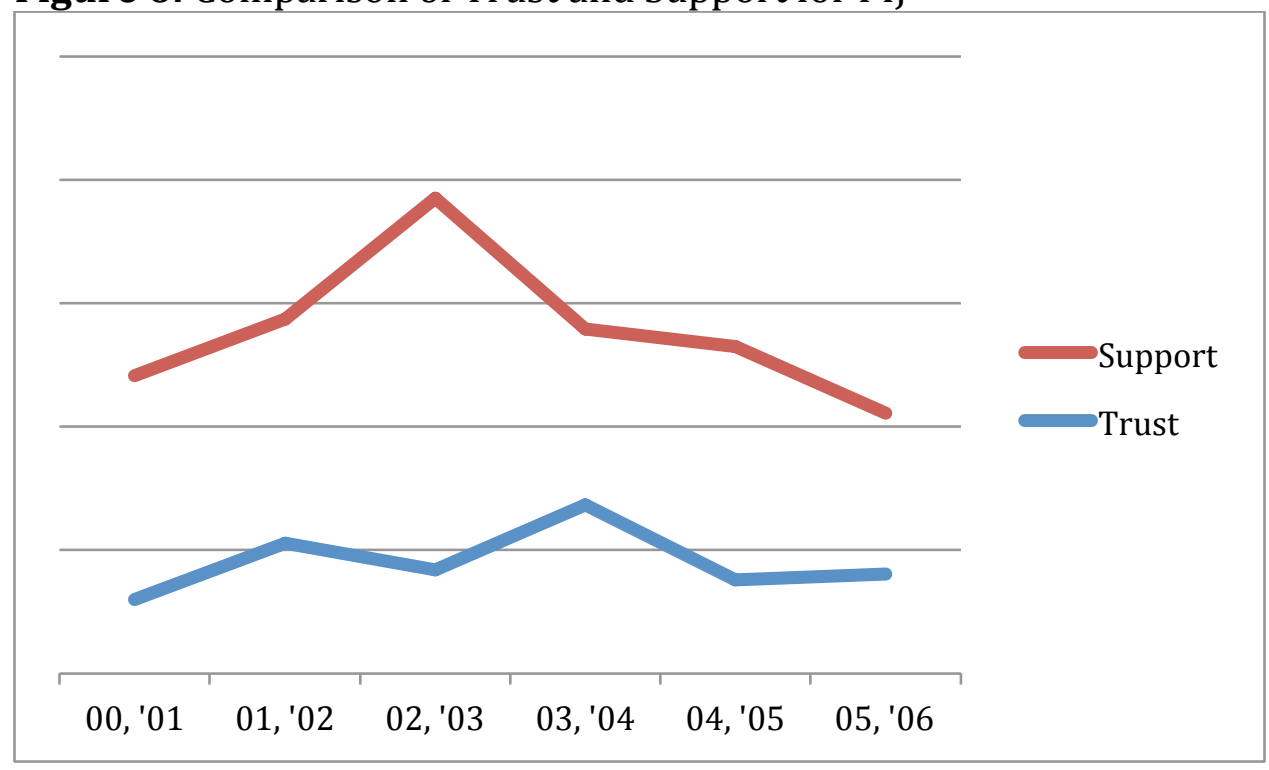

Note: The first year in the pair corresponds to the date point for trust, and the second year to the data point for support.

As mentioned previously, the measure of support for the PIJ is problematic because it is combined with other Islamic Factions. By combining PIJ and the other Islamic groups, the results for the PIJ are likely biased due to measurement error. There are two obvious points of difference. Domestic support rises in 2003, despite the decrease in trust in 2002. Furthermore, domestic support declines in 2004 while trust increased in 2003. A good number of Palestinians do not trust or support any insurgent group. Perhaps they do not see any group as legitimate, or they just want to remain neutral. Figure 7 compares the trust and support levels for those Palestinians who selected no group. The support line generally follows the same pattern as the trust level, although there are some differences in the incline. While there was a slight increase in trust between 2002 and 2003, support for no group declined from 2003 to 2004. 
Figure 7: Comparison of Trust and Support for No One

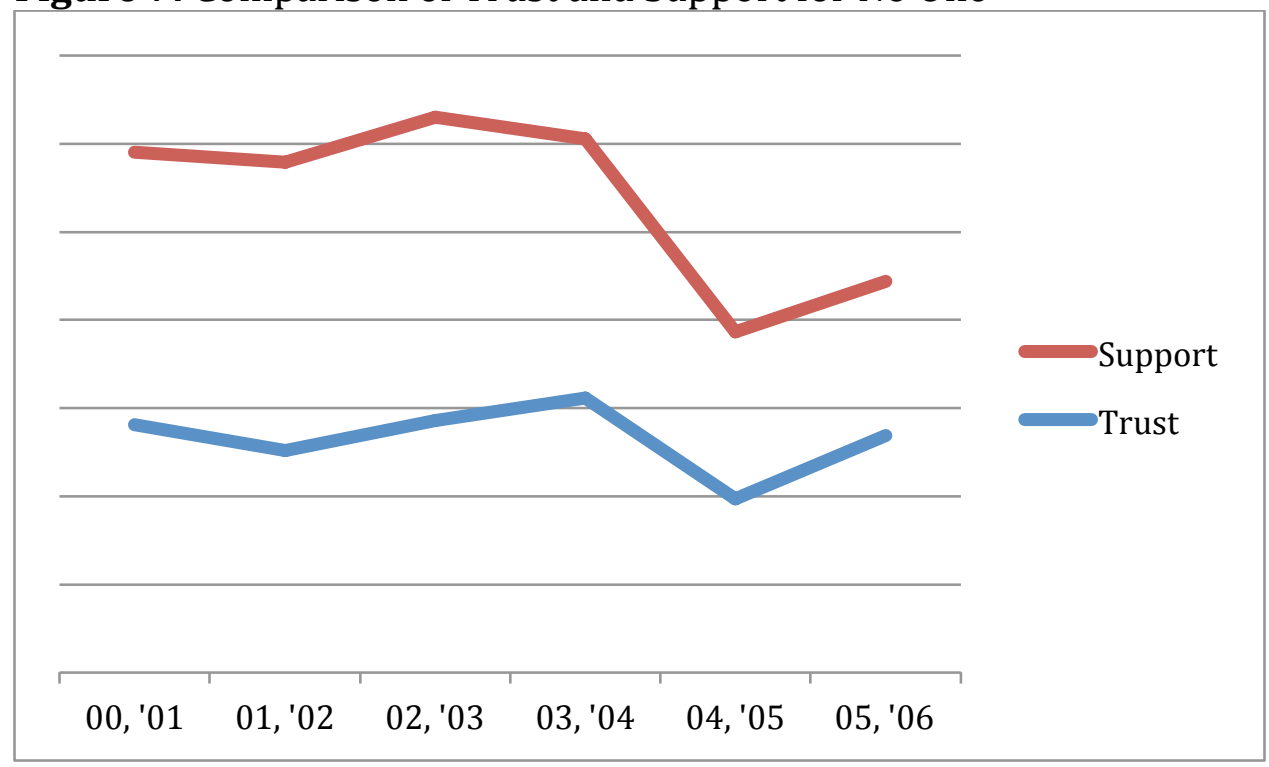

Note: The first year in the pair corresponds to the data point for trust, and the second year to the data point for support.

\section{The Case of Hamas}

The case of Hamas allows us to observe one of the necessary conditions for legitimacy to be achieved: that of service provision. By examining the provisions of services, I can begin to show qualitatively that legitimacy brings about support for a group. Hamas' rise among the Palestinian groups can be partially attributed to the social work that it has been dedicated to providing. This social work comes in various forms including "charities, mosques, unions, schools and sports clubs" (Hroub 2006: 70). An International Crisis Group report written in the middle of the Second Intifada found: "Roughly two-thirds of Palestinians live below the poverty line, and Islamic social welfare organizations, directly or indirectly, provide emergency cash assistance, food and medical care as well as educational and 
psychological services, to perhaps one out of six" (2003: ii). While not all of the Islamic social welfare organizations are affiliated with Hamas, the ICG found between 70 and $100^{19}$ of the groups were out of approximately 700 operational NGOs. ${ }^{20}$

Before the Second Intifada zakat committees helped around 450 families by providing them with monetary assistance, but three years into the conflict the zakat committees assist 6,550 families. ${ }^{21}$ Zakat committees collect and distribute the Islamic version of alms. Not only do the Islamic social organization provide monetary funding to those in need, but they also supply emergency food provisions to "benefit families whose breadwinners lost their jobs, whose homes have been demolished, who have lost family members to the conflict ("martyrs"), or members of whom have been wounded, imprisoned or traumatized."22 Education assistance is another major avenue for social work. For instance, Hamas has a variety of Islamic kindergartens that taught education curriculum approved by the Palestinian Ministry of Education (Roy 2011).

While the provision of services was important, the grassroots social organizations needed to be seen as legitimate as well. Sara Roy argues that Hamas and the Islamic social organizations were legitimized due to four key factors:

[They] had no ideological criteria as conditions for access to Islamic social services; evinced no desire or intent to create a strictly Islamic society or implement any Islamic model; desired greater practical cooperation with the Palestinian government, itself reflecting an openness on the part of the Islamists for better state-society relations and not an attempt to challenge,

19 ICG. 2003, April 2. Pg. 11

20 Roy, Sara. 2011. Pg. 101

21 ICG. 2003, April 2. Pg. 15

22 IBID 
alienate, or sabotage state authority; and prioritized professionalism over ideology. (2011: 90)

By operating within the state system, these groups reinforced their deference to authority that in turn allowed them to garner more legitimacy because the groups showed that are not trying to destroy the state. Rather the social organizations are trying to uphold the legitimacy of the Palestinian state and compete within the system in place for influence. Additionally, as the Islamic social groups did not have any political criteria, they were able to gain the trust of more citizens. UN officials operating in the occupied territories confirmed that Islamic organizations "refrain[ed] from demanding allegiance to Hamas as a condition or quid pro quo for services". ${ }^{23}$

"In Palestinian eyes Hamas has been managing to chart parallel and harmonious paths of both military confrontation against the Israeli occupation, and grassroots social work, religious and ideological mobilization and PR networking with other states and movements" (Hroub 2006: viii). ${ }^{24}$ As Hroub suggests, the provision of services was key to Hamas becoming more legitimate to Palestinians. Hroub's assertions are shared by Sara Roy: “Hamas was proliferating from below, gaining strength and popularity largely from the services provided by its social and charitable institutions, and from the continued perception of Hamas as the only viable political faction resisting the occupation and opposing the violence and corruption of Fatah" (2011: 202). Roy's statement reiterates that the decrease in the legitimacy of Fatah and the increase in services from Hamas led to increased

${ }^{23}$ ICG. 2003, April 2. Pg. 15

${ }^{24}$ Emphasis added 
legitimacy for Hamas. Another way in which Hamas increased its legitimacy through grassroots social work was its means of distribution. Not only did Hamas offer services to supporters, but it also helped any Palestinian in need. For instance, Hamas gave monthly assistance to people who were employed by Fatah and the Palestinian Authority if they were still below the poverty line (Hroub 2006). Other groups recognized the success Hamas had in its social work and the legitimacy it garnered as a result. Therefore, Israel, the United States, and even other Palestinian groups would target Hamas' social network. This strategy employed against Hamas sought to damage its legitimacy, and its results are striking. During 2003 to 2004, after much pressure from Israel and the United States, the Palestinian Authority targeted Hamas' charities. In August 2003, the Palestinian Authority froze 39 bank accounts of nine charities including: Al Jamiya Al Islamiya, the Islamic Young Women's Association, Al Salah Association, the Social Care Committee, the Palestinian Student Friends Association, the Islamic Charity for Zakat, Al Mujamma Al Islami, Al Nour Charity Association, and Al Aqsa Charity Association. At least two of the charities, Al Jamiya Al Islamiya and Al Salah, are confirmed fronts for Hamas according to Palestinian Authority officials. ${ }^{25}$ Local Palestinians were not made aware of the freeze until they went to withdraw welfare payments and were unable to receive their money. In response, approximately 2,000 welfare recipients marched in protest of the Palestinian Authority's decision. One recipient, Hanan Jaress, who receives monthly payments from Al Mujamma Al Islami stated, "This step will make me unable to feed my children. The Palestinian

${ }^{25}$ Jaafar Ashtiyeh. August 28, 2003. USA Today. 
Authority gives me nothing." 26 While the words of Hanan Jaress and the protests of other Palestinians in similar situations appear to suggest that the Palestinian Authority would be the group who would be blamed, but Jaress's statement reminds us that the provision of services is a necessary but not sufficient aspect of legitimacy. However, Figure 5 depicts how the provision of services is necessary. Although Hamas still tried to maintain its service provisions, its legitimacy suffered due to the policy of the Palestinian Authority. From 2003 to 2004, Hamas suffered a decrease in the level of trust that was followed in 2004 to 2005 by a decrease in the amount of support by Palestinians. This example highlights the importance of the provision of services in a fair, consistent matter to legitimacy. The disruption of social work had the desired result for Israel and the Palestinian Authority in lessening the authority of Hamas during this timeframe.

While Hamas suffered this minor setback, they were able to rebound. The freezing of the Islamic charities' bank accounts was only a temporary setback. Hamas was able to solicit funds from the Gulf States and ordinary Palestinians. For instance, on April 9, 2004, in the Gaza Strip after Friday prayer, Hamas appealed to individuals and raised about $\$ 1.2$ million dollars in a single afternoon. ${ }^{27}$ As a result, Hamas was able to rebound from the attack by the Palestinian Authority under the pressure of Israel and the United States. The election was the ultimate test of the growth of Hamas' legitimacy. Khaled Hroub emphasized the legitimacy Hamas had gained in the eyes of Palestinian when he wrote; "Hamas shocked the world in an unexpected way on 25 January 2006 by winning a landslide victory in the election of

26 IBID

27 Hroub, Khaled. 2006. Pg. 72 
the Palestinian Legislative Council. The PLC...represents the embodiment of Palestinian political legitimacy in the West Bank and Gaza strip" (2006: vii). Roy suggests that the elections were a way to stress Hamas' legitimacy, especially in relationship to Fatah. She states, "Electoral campaigns enabled Hamas to appeal to the Palestinian public in a real and broader way, emphasizing its reputation for social and public service, efficiency, and integrity in contrast to Fatah's corruption, lawlessness, and abuses" (2011: 206). Indeed as seen in Figure 2, Hamas had a higher level of support than Fatah did by 2006 (35.93\% v. 34.4\%). One of the reasons Hamas was able to surpass Fatah was that its provision of service was characterized by transparency, especially when compared to Fatah which had been seen as corrupt (Hroub 2006: 70). As mentioned previously, transparency is a key aspect of providing legitimacy to a group, and Hamas' transparency in social work has definitely allowed the group to be deemed trustworthy. Hamas even involved people at the individual level in shaping its election campaign performing local level consultations and surveys so the campaign would reflect local public interest (Roy 2011). "Its emphasis on grassroots consultations and surveys in the shaping of its election program and the selection of its candidates suggests that, in an electoral context, Hamas heeds public opinion" (Gunning 2008: 191). By showing this intense level of interest, Hamas reinforced the Palestinian's trust. One member of the Palestinian electorate, Ka'inat Dogmosh, voted for Hamas despite her family's insistence that she vote for Fatah because Hamas helped fund her education. ${ }^{28}$ The

${ }^{28}$ Laila El-Haddad and Khalid Amayreh. January 26, 2006. Al-Jazeera. 
example of Ka'inat Dogmosh shows that the provision of services does bring about more support for Hamas by rendering them legitimate.

\section{Conclusion}

By showing the similarity between trust levels and the lagged support levels, Figures 4 through 7 lend support to the legitimacy theory. Based on these comparisons, it appears the hypothesis is plausible. While measurement error may be a concern particularly when looking at PIJ, shifts in the trust levels for the Palestinian factions correspond to similar shifts in their support level. More rigorous testing is needed to confirm the legitimacy hypothesis. The data in this study is based on opinion polls, which can be problematic. Although the polls rely on a random sample of Palestinian adults, the JMCC question on which Palestinian group is trusted, is not asked in isolation. Therefore, preceding questions may bias respondents.

The preliminary case study on the provision of services by Hamas emphasizes the necessary, but not sufficient condition for legitimacy. Examining the grassroots social work by Hamas showed the social work's importance to Hamas' electoral success in 2006. As Hamas was able to provide services more efficiently and transparently than Fatah, it was able to capitalize on its increased legitimacy in the election. Hamas' policy of providing services to any Palestinian regardless of their political persuasion makes they even more legitimate in the eyes of their citizens. However, when the Palestinian Authority limited Islamic charities' operations by freezing their bank accounts, Hamas' support suffered due to this 
attack on their legitimacy. Due to the state of Palestine during the Second Intifada with some many individuals in need, the PA was unable to maintain their policy, and Hamas was able to rebound and resume their social work, as well as repair their image as a consistent provider of services.

These findings highlight a significant area of research that would be of interest to policymakers. When looking at armed groups, it appears that greater legitimacy leads to more support. The connection between legitimacy and support highlights ways in which military strategists can attack groups. By eroding trust for a group through the exposure of the unfairness of the organization to it supporters, the United States can lessen the threat that group poses. This finding is especially important when the U.S. conducts counterinsurgency operations because it highlights the importance of propaganda campaigns aimed at targeting the legitimacy of a group. However, this paper brings to light important aspects of legitimacy that previously have not been emphasized. Fairness and transparency are key building blocks to making an organization legitimacy, and these to blocks are what should be specifically targets by strategists.

At the same time, the U.S. must ensure that its own legitimacy is not damaged in the eyes of the local population because this situation would undermine U.S. operations and perhaps push the locals into the arms of the very group we are trying to combat. The U.S. must be fair and transparent in helping the locals or she will undermine her own legitimacy. Additionally, this paper emphasizes the importance of a government maintaining its own legitimacy in the eyes of its people. As we look toward the recent events of the Arab spring and the overthrow of long- 
standing dictatorships in Tunisia, Libya, and Egypt, perhaps these regimes had hit a critical point in which their legitimacy could no longer be salvaged in the eyes of their citizens, so their removal was the only acceptable outcome.

\section{Future Areas of Research}

While this paper presents an alternative explanation for support, it does not test this explanation against existing ones discussed in the literature review. The alternative explanations mentioned previously include: material incentives, defiance, and pleasure in agency. However, the legitimacy hypothesis seems to subsume the material incentives explanation because incentives help determine a group's legitimacy through service provision. Now that the plausibility of the legitimacy hypothesis has been asserted, it needs to be tested against these other explanations. One way to move forward in this respect is to collect individual testimony about the reason why individuals support one faction versus another. Furthermore, the paper's research design limits the hypothesis testing solely to the Arab-Israeli conflict. As a result, the findings may not be generalizable to other cases. More testing is needed in other civil war contexts to reaffirm the findings of this paper.

Another area of future research is to look at whether support is affected by the violation of a group's doctrine. Insurgent groups that break their own doctrine will damage their image as a trustworthy group and will lose legitimacy as a result. For instance, a key aspect of the doctrine for Hamas and the PIJ is the armed struggle or jihad. While Fatah maintains the necessity of an armed struggle, it is a 
watani or national struggle, not jihad. Since Hamas and the PIJ call for a jihad, they must obey by the rules of jihad. What exactly are the rules of jihad, and do these groups obey them? If Hamas or the PIJ disobey the rules of jihad, then they are contradicting their doctrine. By contradicting their doctrine, these Palestinian factions may be hurting their legitimacy in the eyes of Palestinians. The rules of jihad can be summed up as followed:

The opponent must always have started the fighting. It must not be fought to gain territory. It must be launched by a religious leader. It must be fought to bring about good - something that Allah will approve of. Every other way of solving the problem must be tried before resorting to war. Innocent people should not be killed. Women, children, or old people should not be killed or hurt. Women must not be raped. Enemies must be treated with justice. Wounded enemy soldiers must be treated in exactly the same way as one's own soldiers. The war must stop as soon as the enemy asks for peace. Property must not be damaged. Poisoning wells is forbidden. The modern analogy would be chemical or biological warfare. (BBC) ${ }^{29}$

To examine if Hamas and PIJ are violating their doctrine, and therefore damaging their legitimacy, a future paper could focus on the rule of not killing women or children. Prohibiting the killing of women and children stems from the Hadiths or the deeds and sayings of the Prophet Muhammad. As women and children are sometimes inadvertently killed, an interesting avenue of research would be how Hamas and PIJ circumvent the issue of legitimacy while retaining this form of political resistance. B'Tselem, the Israeli Information Center for Human Rights in the Occupied Territories, collects data on the fatalities on both sides of the ArabIsraeli conflict. From September 2000 to January 2006, 38 Israeli minors were killed in the occupied territories, and 78 Israeli minors were killed in Israel. ${ }^{30}$

${ }^{29}$ http://www.bbc.co.uk/religion/religions/islam/beliefs/jihad_1.shtml\#top $30 \mathrm{http} / /$ www.btselem.org/statistics/fatalities/before-cast-lead/by-date-of-event 
During this same period, 50 Israeli women were killed in the occupied territories and 162 in Israel. ${ }^{31}$ However, B'Tselem does not assign responsibility for the fatalities. Locating the responsibility for the fatalities would allow the researcher to test if breaking the doctrine leads to a decrease in support.

Similar to the thought process behind the examination of breaking the doctrine, a different approach to take would be to look at the election campaign. During the election campaign Hamas made promises to the Palestinians. Did Hamas follow through on their campaign promises? If not, did this affect their legitimacy and level of support? This area of research could be pursued qualitatively by talking to the electorate. By looking at the most important issues to voters, one can see if the Palestinian people paid attention to campaign promises on these issues. If Hamas failed to follow through on those issues, did those people switch to support another group in the next election? The analysis of the Second Intifada shows that the legitimacy theory has merit; however, further tests are needed.

\section{Appendix}

Figure 3: Average Percentage of Trust for the Major Palestinian Factions Year

\begin{tabular}{lrrrrrr}
\hline Factions & 2000 & 2001 & 2002 & 2003 & 2004 & 2005 \\
Fatah & 32.1 & 31.325 & 29.45 & 25.95 & 41.4 & 37.5 \\
Hamas & 19.5 & 19.575 & 20.85 & 25.95 & 20 & 37.5 \\
PIJ & 3 & 5.275 & 4.2 & 6.85 & 3.8 & 4.05 \\
None & 28.1 & 25.2 & 28.575 & 31.15 & 19.7 & 26.85 \\
\hline
\end{tabular}

Source: JMCC Public Opinion Poll Data

31 IBID 


\section{Bibliography:}

Al-Faluji, 'Imad. 2001, March 21. PA Minister: The Intifada Was Planned From the Day Arafat Returned From Camp David. The Middle East Media Research Institute. Retrieved from http://www.memri.org/report/en/0/0/0/0/0/0/432.htm

Ashtiyeh, Jafaar. 2003, August 28. Palestinian Authority Freezes Funds of Islamic Charities. USA Today. Retrieved from http://usatoday30.usatoday.com/news/world/2003-08-28-mideastcharities_x.htm

Baroud, Ramzy. 2006. The Second Palestinian Intifada: A Chronicle of a People's Struggle. London: Pluto Press.

Cohen, Eliot; Jan Horvath, and John Nagl. 2006. Principles, Imperatives, and Paradoxes of Counterinsurgency. Military Review. 86(2): 49-53.

Eikenberry, Karl W. 2013. The Limits of Counterinsurgency Doctrine in Afghanistan. Foreign Affairs. 92(5): 59-74.

El-Haddad, Laila and Khalid Amayreh. 2006, January 26. High Turnout at Palestinian Polls. Al-Jazeera. Retrieved from http://www.aljazeera.com/archive/2006/01/200849142525694946.html

Farsoun, Samih K. and Naseer H. Aruri. 2006. Palestine and the Palestinians: A Social and Political History. Boulder, CO: Westview Press.

Goldenberg, Suzanne. 2000, September 28. Rioting as Sharon visits Islam Holy Site. The Guardian. Retrieved from http://www.theguardian.com/world/2000/sep/29/israel

Gunning, Jeroen. 2008. Hamas in Politics: Democracy, Religion, Violence. New York: Columbia University Press.

Helfont, Tally. 2009. The Palestinian Islamic Jihad's U.S. Cell: The Ideological Foundations of its Propaganda Strategy. Foreign Policy Research Institute. Ebook.

Hroub, Khaled. 2006. Hamas: A Beginner's Guide. London: Pluto Press.

Humphreys, Macartan and Jeremy Weinstein. 2008. Who Fights? The Determinants of Participation in Civil War. American Journal of Political Science. 52(2): 436455.

International Crisis Group. 2003, April 2. Islamic Social Welfare Activism in the Occupied Palestinian Territories: A Legitimate Target? Report No. 13. Amman/Brussels: ICG.

Jaeger, David A.; Esteban F. Klor; Sami H. Miaari; and M. Danielle Paserman. 2010. The Struggle for Palestinian Hearts and Minds: Violence and Public Opinion in the Second Intifada. Belfer Center for Science and International Affairs. MEI Conference Paper. < http://belfercenter.ksg.harvard.edu/files/uploads /mei/conference/paserman-palestinianheartsandminds.pdf>

Jaeger, David A.; Esteban F. Klor; Sami H. Miaari; and M. Danielle Paserman. 2011. Can Militants Use Violence to Win Public Support? Evidence from the Second Intifada. Journal of Conflict Resolution. Forthcoming. 
<http://people.bu.edu/paserman/papers/Jaeger-Klor-Miaari-

Paserman_CanMilitantsUseViolence_February2011.pdf $>$

JMCC Public Opinion Poll. 2001, December. On Palestinian Attitudes Towards Politics including the Current Intifada. Jerusalem Media and Communications Center. Retrieved from http://jmcc.org/

Levi, Margaret; Andrew Sacks; and Tom Tyler. 2009. Conceptualizing Legitimacy, Measuring Legitimating Beliefs. American Behavioral Scientist. 53(3): 354375.

Norman, Julie. 2010. The Second Palestinian Intifada: Civil Resistance. London \& New York: Routledge.

Olson, Mancur. 1965. The Logic of Collective Action: Public Goods and the Theory of Groups. Cambridge, Massachusetts: Harvard University Press.

Pearlman, Wendy. 2003. Occupied Voices: Stories of everyday life from the Second Intifada. New York: Thunder's Mouth Press

Popkin, Samuel L. 1979. The Rational Peasant: The Political Economy of Rural Society in Vietnam. Los Angeles: University of California Press.

Pratt, David. 2006. Intifada: The Long Day of Rage. Philadelphia: Casemate.

Roy, Sarah. 2011. Hamas and Civil Society in Gaza: Engaging the Islamist Social Sector. Princeton: Princeton University Press.

Seligson, Mitchell A. 2002. The Impact of Corruption on Regime Legitimacy: A Comparative Study of Four Latin American Countries. The Journal of Politics. 64(2): 408-433.

Schanzer, Jonathan. 2008. Hamas vs. Fatah: The Struggle for Palestine. New York: Palgrave Macmillan.

Shamir, Jacob and Khalil Shikaki. 2010. Palestinian and Israeli Public Opinion: The Public Imperative in the Second Intifada. Bloomington, Indiana: Indiana University Press.

Tyler, Tom R. 2006. Psychological Perspectives on Legitimacy and Legitimation. Annual Review of Psychology. 57: 375-400.

Weber, Marx. 1947. The Theory of Social and Economic Organization. New York: The Free Press.

Whitaker Brian. 2005, September 13. How Mubarak Won the Election. The Guardian. Retrieved from http://www.theguardian.com/world/2005/sep/13/worlddispatch.egypt

Wood, Elisabeth Jean. 2003. Insurgent Collective Action and Civil War in El Salvador. Cambridge: Cambridge University Press. 